\title{
Personal Needs Assessment Approach in Strategic Training and Affective Commitment
}

\author{
Roya Anvari (Corresponding author) \\ Faculty of Management and Human Resource Development \\ Universiti Teknologi Malaysia, Johor 81310, Malaysia \\ Tel: 60-1-7753-1256 E-mail: ry_anvari@yahoo.com \\ Salmiah bt Mohamad Amin \\ Faculty of Management and Human Resource Development \\ Universiti Teknologi Malaysia, Johor 81310, Malaysia \\ E-mail: salmiah@utm.my \\ Salbiah Seliman \\ Faculty of Management and Human Resource Development \\ Universiti Teknologi Malaysia, Johor 81310, Malaysia \\ E-mail: salbiahseliman86@gmail.com
}

\begin{abstract}
This paper aims at determining the relationships between psychological contracts, job involvement, affective commitment, and three dimensions of personal needs assessment in strategic training (i.e. motivation to learn, perceived support, and training attitudes) in the Iranian hospitality industries. A questionnaire survey was conducted among the full-time administrative employees of five-star hotels in the Isfahan region, which is an important tourism destination especially for Europeans and Russians in Iran. This study highlights the importance of strategic need assessment in training employees in order to foster their affective commitment. These findings have important practical and theoretical implications. Firstly, managers will not be able to foster affective commitment through human resource practices unless they recognize and appreciate which needs are valued by employees. Secondly, managers must have a clear understanding of both the quantity and quality of information desired by employees if they are to design high-commitment of strategic human resource management practices that meet the information needs of employees. Finally, the results provide evidence in favor of managerial interventions aimed at enhancing organizational commitment and, consequently, minimizing the negative effects of an actual turnover in the hospitality industry.
\end{abstract}

Keywords: Motivation to learn, Training attitude, Perceived support, Affective commitment, Psychological contract, Job involvement

\section{Introduction}

Employee turnover represents a critical problem to an organization in terms of loss of talent, additional employment and training costs (Loi, et al., 2006). Organizational commitment has been considered as one of the most important predictors of turnover and intention to leave. It was found that employees who were more committed to their organizations had lower intention to leave than those with lower organizational commitment (Griffeth \& Hom, 1995; Igharia \& Greenhaus, 1992). With the hospitality and tourism industry's need to employees training and maximize quality results, the concept of high organizational commitment and low actual turnover are most important, because encouragement and support for training can be a critical factor in influencing commitment and turnover. In light of this, there is an obvious need for further research on organizational commitment in hospitality and tourism businesses around the world (D'Annunzio-Green et al., 2002). 
Almost every employee in the tourism industry receives some type of training during his or her career (Mahmoodi, 2007). Although training is big business in terms of both the amount of effort expended and the money spent (Goldstein, 1993, p.4), tourism businesses continue to place greater pressure on training to contribute towards desired organizational outcomes. This is because the turnover rate of the hotel employees was found between the range of 35 percent and 64 percent in a research conducted in the major tourism regions of Iran (Mahmoodi, 2007). High turnover rate of the tourism industry in Iran causes higher costs and lower service quality.

In addition, the expanded role of training places continued pressure on strategic human resource management to develop more effective training strategies and to conduct evaluations that demonstrates a return to the organizations from their training investments (Richard, 2009). In the strategic human resource management literature, strategic training acts as an important factor for lowering turnover and improving organizational performance (Richard et al., 2009). One way in which this can be achieved is in the provision of strategic training and fostering high organizational commitment to enhance the retention of employees in hospitality and tourism businesses.

Despite a wealth of literature on both training and organizational commitment, little is known of their relationship. A better understanding of factors that are associated with organizational commitment can be helpful in designing policies and interventions to increase staff commitment and diminish turnover. There is little knowledge on the relationship between individual-centered needs assessment approach in training and measuring of affective organizational commitment. In addition, this research examined if job involvement and psychological contract mediate the relationship between strategic training and organizational commitment. Also, this research adds knowledge to the strategic human resource management literature about individual-centered needs assessment approach of the hospitality industry in Iran and their relationship to affective commitment.

\section{Review of the Literature}

\subsection{Strategic Training}

Strategic human resource management researchers define human resource management practices such as training as the types of activities that affect behavior of individuals in their efforts to formulate and implement the strategic needs of the organization (Huselid et al., 1997; Becker et al., 1996; Deery et al., 1994; Guest, 1987; Iles et al., 1990; Meyer and Allen, 1997). Tanannenbaum et al. (1991) found a strong positive correlation between commitment and emplolyees' motivation for training. Also, employees exposed to more training opportunities are likely to exhibit higher levels of affective commitment (Meyer, \& Allen, 1991). According to Lang (1992) perhaps training should be specifically designed to achieve increased organizational commitment. In fact, organizational commitment is able to solve basic management problems (Salaman et al., 2005) in order to achieve individual effectiveness, that is, organizational commitment as a factor of work-related attitude and training as an instrument have impact on individual effectiveness (Ahmad \& Bakar, 2003) including, actual turnover.

In a relationship between organizational commitment and training a sample of the numerous possible antecedents that have been explored include perception, and benefits such as career, job related, personnel (Mathieu and Martineau, 1997), satisfaction (Tannenbaum et al,1991), self-efficacy (Saks,1995), social support (Facteau et al, 1995), facilities, materials and equipments (Gomez-Mejia et al., 1995).

Although a variety of studies have been reported recently examining certain aspects of commitment and training, from a strategic approach it is admittedly limited. The findings do provide some support for the argument that strategic training practices are designed to foster organizational commitment and reduce actual turnover. This strategic approach to training is an implication of a strategic human resource management practice that involves abandoning the mindset and practices of "personnel management" and operational issues and focusing on strategic issues Mello (2002:100). Therefore, from the employee's point of view, training is a character of the employers' commitment to their staff (Storey and Sisson, 1993).

In addition, according to Farrell and Rusbult (1981) exchange theory suggests that training can be viewed as an investment in the relationship between an organization and the employees and can contribute to organizational commitment. The more positive the training experience, the greater can the commitment be to the organization. Organizational commitment is positively related to the employee's attitude towards training and training motivation (Carlson et al., 2000). According to Blau (1964), "Social exchange... refers to voluntary actions of individuals that are motivated by the returns they are expected to bring and typically do in fact bring from others". Cook and Rice (2003) noted social exchange as the process by which individuals and group give resources to other social individuals, group and organization and receive resources from them. According to 
Rousseau (1989) the terms and conditions of this reciprocal exchange between organizations and their employees are defined within in the psychological contract. He also describes that psychological contract is an employee's belief regarding terms and conditions of an exchange relationship with their organization. It constitutes of employment obligations, embedded in the context of social exchange. Strategic human resource management practices affect the psychological contract (King, 2000; Guzzo and Noonan, 1994).

A psychological contract is created when organizations and their representatives convey promises of future inducements (training) to the employees in exchange for some contribution from the employees who help them understand terms of their employment (Rousseau \& Greller, 1994). It has been argued that human resource management practices including training can send strong messages to individuals regarding what an organization expects of them and what they can expect in return, and hence training are seen to play an important role as message senders, shaping terms of the psychological contracts (Rousseau \& Wade-Benzoni, 1994). Hence, a major function of training is to foster an appropriate psychological contract (Rousseau \& Greller, 1994), and employee interpretations of their employer's training may affect their psychological contract with their employer, and ultimately their perception of contract fulfillment or breach may affect their commitment to their employer.

As a result, in the present study, it is theorized or hypothesized that industries' managers can influence workrelated attitude such as organizational commitment through the maintenance of the strategic training, reduce turnover intention and enhance effectiveness.

One of the most important keys to developing successful training programs in organizations is strategizing the training. This involves needs assessment (Mello,2002). Athought needs assessment involves three levels of analysis such as organization, task, and personal, in this research it was theorized that the more precisely managers can influence organizational commitment throught individual level of needs assessment of startegic training. Because this level of needs assessment considers the people to be commited, only analysing individual needs shows a lack of adequate planning and strategising on the part of organization (Anthony et al., 1999).

In addition, it is thought that highly committed organizations use strategic training practices to make more informed decisions with good consequences. This requires an analysis of levels of knowledge, personal growth, motivation to learn (Hicks, 1984) and personnel attitude that play a role in determining trainability (Noe and Schmitt,1986). Also, this analysis is based on personel needs assessement of training focuses on the organization-person fit (Daley, 2002) that may lead to affective commitment.

It is important to remember that organizational commitment provides a basis for understanding the development of linkages between individuals and organizations (Chew and Chen, 2008). Although, some emprical supports show that person-organization fit is positively linked with organizational commitment and is negatively related to turnover intention (Studies by Becker et al, 1996; Chew \&Chen, 2008) there remains a shortage of empirical support for the notion that needs assessment of personal which is essential if training is to be linked to affective organizational commitment. Unfortunetly, such link is little investigated. Iranian hospitality industries are organizations that rush to provide training solutions to their problems such as turnover intention, low interest to learn, and lack of support, without adequately assessing personal needs. Training needs assessment is a tool that helps them create a superior workforce (http: //humanresources. about.com /od/trainingneedsassessment / Training_Needs_Assessment. htm.)

Furthermore, strategic human resource management practices are concerned with longer-term people issues (Armstrong, 2000) and within this framework it is nessessary to consider long-term strategies of training. For example, it should provide appropriate support, and it would be necessary to address personal attitude and motivation to learn within the organizations to ensure participation and percived support. However, organistions can also achieve immediate improvements in performance and result if short-term management approach applies effective training (Thomas, 2000).

\subsubsection{Motivation to Learn}

The motivational level of employees is a foundational component of the effectiveness of organizational training programs. Goldstein $(1991,1992)$ emphasized the importance of motivation: 'Before trainees can benefit from any form of training ... they must be motivated' (1991 p. 541). Noe and Wilks argued that 'motivation to learn, and evaluation of previous development experiences have a direct effect on employee's participation in development activities' (1993: 292). They developed and tested a conceptual model of development activity that was based on work conducted by Dubin (1990), Farr and Middlebrooks (1990) found that motivation to learn, perception of benefits and work situation perceptions had considerable, unique effects on employee development activity. 


\subsubsection{Percived Support}

Huczynski and Lewis (1980) concluded that issues important to whether or not trainees use their training included whether they attended the course on their own initiative; how helpful they believed the training would be to them in their jobs; and the motivational climate of the organization, in particular, supervisor support. In addition, employees are often influenced by the level of and the manner in which they interact with their supervisors (Eisenberger et al., 2002). When supervision creates an environment where there is a sense of belonging, and demonstrates effective training, employees will display strong feelings of commitment (Ammeter \& Dukerich, 2002). In addition, supervisor support has been shown to enhance employee job attitudes such as organizational commitment (Thompson \& Prottas, 2005) and is negatively related to turnover intentions (Thompson et al., 1999). Supervisor support, a source of social support, is related to work attitude (Hammer et al., 2009) and they are responsible for training. Also, they motivate employees toward acceptable behaviors such as commitment (Caykoylu et al., 2007). Furthermore, training attitudes indicate levels of good or bad feeling about training. Hicks (1984) argued that if employees are given reasonable information about the training program, the employees can see how training fits with their needs. So, if the employees feel that the match is good, they should have a heightened desire to learn (Porter et al., 1974), which is a prerequisite for strategizing training.

\subsubsection{Training Attitudes}

Training attitudes indicate levels of good or bad feeling about training. Hicks (1984) argued that if employees are given reasonable information about the training program, the employees can see how training fits with their needs. So, if the employees feel that the match is good, they should have a heightened desire to learn (Porter et al., 1974), which is a prerequisite to strategize training. It is clear that training attitudes in strategizing training as a dimension of personal analysis needs was discovered by results (Hicks 1984) indicated that employees who received the reasonable training and those who had a higher degree of choice were more likely to perceive the seminar to be appropriate for them to take and were better able to profit from training. Also, they were also more committed to their decisions to attend the training.

In ligh of this, if employees in the Iranian hospitality industries have learnt new skills and knowledge and successfully implemented this learning to enhance the performance of the organization, they should be compensated accordingly in a way that is significant to them. As a result, according to Garger (1999) the challenge for business today is to provide development opportunities and alignment between these strategies, the most likely to see improvement in both satisfaction of the employees of the hospitality industry in Iran and actual turnover. Based on these arguments, the following hypotheses were advanced:

Hypothesis 1: Individual needs assessment of strategic training (motivation to learn, perceived support, and attitudes) will be positively related to affective commitment.

Hypothesis 1.a: Motivation to learn will be positively related to affective commitment.

Hypothesis 1.b: Perceived support will be positively related to affective commitment.

Hypothesis 1.c: Training attitudes will be positively related to affective commitment.

\subsection{Organizational Commitment}

Meyer and Allen (1991) commented on the various definitions of organizational commitment to include "the view that commitment is a psychological state that (a) characterizes the employee's relationship with the organization, and (b) has implications for the decision to continue membership in the organization" (p. 67). Thus, regardless of the definition, committed employees are more likely to remain in the organization than are uncommitted employees. What differs across definitions is the nature of the psychological state being described. According to Meyer and Allen (1991), the three states are as follows:

"Affective (commitment) refers to the employee's emotional attachment to, identification with, and involvement in the organization. Employees with a strong affective commitment continue employment with the organization because they want to do so. Normative commitment reflects a feeling of obligation to continue employment. Employees with a high level of normative commitment feel that they ought to remain with the organization. Finally, continuance commitment refers to an awareness of the costs associated with leaving the organization. Employees whose primary link to the organization is based on continuance commitment remain because they need to do so". Meyer and Allen (1991) described these dimensions as components rather than types of commitment, as they postulated that they were not mutually exclusive. The components were felt to reflect a psychological state, and any individual could experience all three components of commitment to varying degrees (Meyer and Allen, 1997). Due to the conceptual differences in the components, they hypothesized that each 
component would have different antecedents and differences in work-related behavior such as actual turnover. As a result, Meyer, Allen and their colleagues (e.g. Allen and Meyer, 1990; Meyer and Allen, 1984, 1991; Meyer et al., 1990; Meyer et al.,1993; Meyer et al., 1989) view affective, normative and continuance commitment as components of attitudinal commitment (Iverson and Buttigieg, 1999). However, according to Iverson and Buttigieg (1999), affective commitment is the most consistent factor with the conceptual and operational definition of attitudes, so it has been termed "attitudinal commitment". In other words, affective commitment is a psychological and individual-level (Elias, 2009). Consequently, for this study we want to focus on this aspect of commitment in Meyer and Allen's three-component commitment model.

Furthermore, organizational commitment is especially important for the service sector businesses (Sarmad, 2005). As employees are the very first people who meet the requirements of guests, organizational commitment, which affects the behaviors of employees, has a distinct place in service industries. Because employees have relationships with guests in hotel businesses and accordingly they play key roles in guest satisfaction, top managers should rather consider organizational commitment of their employees (Güc, lu", 2006).

\subsubsection{Affective Commitment and Turnover Intention}

Organizational commitment as defined by Meyer and Allen (1991) is a three-element model, which involves a link between the employee and probability of the employee leaving the organization. These three components are affective, continuous and normative. Although the relationship may be more complex than initially suggested by them, co relational analysis has suggested that each component of commitment was extensively and negatively related to turnover intention, but the strengths of the correlations differed among the three components (Mthieu \& Zajac, 1990; Meyer et al., 2002; Williams \&Hazer, 1986).

Meyer and Allen (1991) found that continuance commitment and normative commitment added little variance over affective commitment to turnover. For example, the results from meta-analyses have shown that affective and normative commitment have negative relationships with turnover $(\mathrm{r}=-.01$ and $\mathrm{r}=-.16$ respectively) and withdrawal cognitions $(r=-.56$ and $r=-.33$ respectively; Meyer et al., 2002). In fact, three components of organizational commitment were negatively correlated with turnover and with affective commitment being the most robustly correlated.

Williams and Hazer (1986) found that affective commitment was clearly shown to have a significantly stronger correlation with turnover intention than normative or continuance commitment. Likewise, Mathieu and Zajac (1990) showed the relationship between intention to leave and turnover using the three-component model in a met- analysis of 14 studies and found these outcomes were most strongly correlated with affective commitment.

It is for these reasons that we want to focus on this affective aspect of commitment, rather than all three forms of commitment. Based on these arguments, the following hypotheses were advanced: Hypothesis 2: Affective commitment will be negatively related to turnover intention.

\subsection{Psychological contract}

Argyris (1960), Levinson et al.(1962), and Schein (1965), developed a psychological contract theory as a framework for understanding the employment relationship (Shore et al., 2004; Taylor \& Tekleab, 2004) i.e. mutual obligations (Rousseau \& Tijoriwala, 1998; Rousseau, 1989), or legal contract (Zhao et al., 2007). Psychological contracts are defined "as the beliefs individuals hold regarding the terms and conditions of the exchange agreement between themselves and their organizations" (Rousseau, 1995, p. 9) or an "individual's belief in the terms and conditions of a reciprocal exchange agreement between the focal person and another group" (Rousseau, 1989, p. 123). In other words, psychological contracts refer to "employees" "perceptions of what they owe to their employers and what their employers owe to them" (Robinson, 1996, p.574). Furthermore, psychological contracts are highly subjective (Guzzo and Noonan, 1994; Guest, 1998). Also, Schein (1965) emphasized the importance of the psychological contract concept in understanding and managing behavior in organizations. So, psychological contract theory can also be used to understand commitment. Although, employee perceptions of the psychological contract and commitment to the organization are theoretically linked, and there is some empirical support for this relationship (e.g., Bunderson, 2001; Lester et al., 2002; Sels et al., 2004), research has not kept rapidity with recent developments in the broader contracts and commitment literatures (McInnis et al., 2009). In addition, context-specific differences between organizations, within organizations and among individuals are more essential for the creation, improvement and evaluation of the psychological contract (Huiskamp \& Schalk, 2002). Therefore, it was predicted that psychological contract mediates the relationship between training and organizational commitment. Hypothesis3: Psychological contract will be positively related to affective commitment. Hypothesis4: Individual needs assessment of strategic training (motivation to learn, perceive support, and attitudes) will be positively related to psychological contract. 
Hypothesis 4.a: Motivation to learn will be positively related to psychological contract.

Hypothesis4.b: Perceive support will be positively related to psychological contract.

Hypothesis 4.c: Training attitudes will be positively related to psychological contract.

Hypothesis5: Psychological contract will mediate the relationship between individual needs assessment of training and affective commitment.

\subsection{Job involvement}

The possible relationship between three dimensions of individual needs assessment approach and affective commitment is most likely moderated by other workplace attitudes. According to Blau and Boal (1987) job involvement has been found to interact with organizational commitment such that someone who is both involved in their job and committed to their organization will be more likely to stay with their organization. Also, Mathieu and Zajac (1990) made a meta-analysis that examined the relationships among antecedents, correlates, and consequences of organizational commitment. They found moderate relationship between job involvement and organizational commitment and the relationship between job involvement and affective commitment was stronger than that of job involvement and continuance commitment. Consequently, the present study focuses on organizational commitment of hotel employees and its correlates, and it is expected to find the relationships between job involvement and three dimensions of training needs assessment and organizational commitment. Therefore, it was predicted that job involvement mediates the relationship between training and organizational commitment. So, the following hypotheses are proposed:

Hypothesis6: Job involvement will be positively related to affective commitment.

Hypothesis7. Individual needs assessment of training will be positively related to job involvement.

Hypothesis 7.a: Motivation to learn will be positively related to job involvement.

Hypothesis 7.b: Perceived support will be positively related to job involvement.

Hypothesis 7.c: Training attitudes will be positively related to job involvement.

Hypothesis8: Job involvement will mediate the relationship between individual needs assessment and affective commitment.

\section{The Research Model}

Based on past research presented in the literature review, a structural model of affective commitment and its correlates was developed. The model postulates the relationships between psychological contract, job involvement, and affective commitment and three dimensions of strategic training (motivation to learn, perceived support, and attitudes) (Figure 1). According to this model, job involvement, psychological contract, and all three training needs are related to affective commitment.

\section{Method}

\subsection{Participants and procedure}

The empirical study for this research was conducted in five-star hotels located in Isfahan, which is one of the largest cities in the northeast of Iran with a resident population of about one million, and the second most important tourism destination in Iran. Today, Iran is one of the most exciting emerging markets in the world. Iran has skilled managerial and technical manpower that match the best, available in the world. In today's market environment, it is widely known that organizations compete head-to head with rival firms for control of customers, market share and revenue to achieve a leadership position in their chosen modes of operation. Companies are trying hard to retain their priced talent. The Iranian hospitality industry is no exception and is also witnessing high turnover. The target population for this study consists of employees in hospitality industry in Iran. The sample frame for this study consisted of employees in a hospitality company in Isfahan, that is, the empirical study for this research was conducted in five-star city hotels located in Isfahan.

As data collection tools, questionnaires were distributed by each hotel's human resources department with supervision of the authors of this study, in order to be answered by the full-time hotel employees. Out of 1300 questionnaires distributed, 480 were returned, out of which 436 surveys were valid. Also, a total of 436 questionnaires were used for analysis that response rate of this study was 41 percent. A total of 84.5 percent of the respondents were women and 14.3 percent were men and 1.2 percent were missing cases. The tenure of the sample was 12.1 years. Of the employees, 38 percent were between 22 and 53 years old, 11.3 percent have high school degrees, and 68 percent have college diploma. Approximately 72 percent of respondents ranked 4 to 6 , 
which represents middle manager positions in organizational hierarchy; For tenure with the current employer, most respondents indicated that they had worked for one-two years $(n=21 ; 24.2 \%)$, followed by more than four years $(n=21 ; 23.1 \%)$, followed by six months-one year $(n=19 ; 20.9 \%)$, two-three years $(n=13 ; 14.3 \%)$, less than six months $(n=12 ; 13.2 \%)$ and the smallest number of employees self reported to have been working in the organization for three-four years $(n=4 ; 4.4 \%)$.

The participants were informed about confidentiality issues and that they had been given the right to withdraw from the study at any time and any stage.

\subsection{Measures}

All items in the questionnaire were measured on a five-point Likert scale $(1=$ strongly disagree; 5 =strongly agree).

Motivation to learn. Sample items on motivation to learn scale developed by Noe and Schmitt (1986) was used. An example, "I am motivated to learn the skills emphasized in the training program". In addition, the motivation subscale of the START instrument, with an alpha coefficient of 65, was also used in this study as a measure of motivation to learn. Sample items from this scale include the following: 'I come to training sessions unprepared' (reverse coded), 'I can easily find an excuse for not completing a training program assignment' (reverse coded) and 'I work hard to do well in training programs, even when I don't like them.'

Perceived support. Measures for this dimension were drawn from existing research instruments. Employees' perceptions of the extent to which supervisors reinforce and support the use of learning on the job were measured using a 23- items subscale. Examples of the types of questions included in this scale were, "My advisor involves me in work related decisions based on my training". In addition, the employees' perceptions of their peers' reinforcement and support of the training on the job were measured using a 7- item subscale derived from the other research. Examples of this item included in the scale were," My peers and I discuss how to apply our training on the job".

Training attitudes. Attitudes which trainees have developed about safety and procedures training were measured using a 7- item scale. Measures for this dimension were drawn from the existing research instrument, Strategic Assessment of Readiness for Training (START) (Weinstein et al., 1994). This 7-item subscale from the START instrument was used to measure attitudes held by individuals toward training. Examples of items included in this scale are: 'I believe learning is important for professional development', 'I believe training programs are important for professional development' and 'I volunteer to participate in training programs'. The START instrument was designed to serve multiple purposes (Weinstein et al.1994), including: 1 . To provide a diagnostic assessment of learning strengths and weaknesses in a work setting; 2 . To provide baseline data about readiness to profit from training or other learning experiences early in the training needs assessment process; and, 3. To increase individual's awareness of strategic learning strengths and weaknesses (Weinstein et al. 1994: 24).

Affective commitment. The organizational commitment measurement included affective commitment that refers to an individual's emotional attachment to the organization (Meyer and Allen, 1997). Affective commitment was measured with 6 items that were originally used by Rhodes et. al., (2001). Furthermore, Meyer et al., (1990) developed the tool into a short form. An example item is: "I feel personally attached to my organization".

Psychological contracts. In this study the type of measure for psychological contracts was composite measure. This type of evaluation refers to different content items of the psychological contract (e.g., high pay, training, and job security) and asks respondents how much the organization has fulfilled its obligation or guarantee on each item or had actually been provided. In addition, a composite measure of breach uses content-specific items, and the contents can be categorized into two types of contracts: obligations about high pay and merit pay (Rousseau, 1990) and obligations about personal support and a meaningful job) and long-term exchanges that maintain the employee- employer relationship (e.g., training, see Coyle-Shapiro \& Kessler, 2000). As a result, at the same time respondents indicated the extent to which they believed their employer was obliged to provide or had actually been provided, a list of 12 items (Coyle-Shapiro \& Conway 2005). As noted above, these items capture portions of the employment relationship studied in the majority of previous research (Rousseau, 1990; Robinson et al., 1994; Coyle-Shapiro \& Kessler, 2000; Lofquist, 1967). The estimated or subjective probability of job involvement was measured by using six items from the larger Lodahl and Kejner (1965) scale. In addition, these items focus on employees' perceptions of the importance of work in general.

Turnover intention. The scale which was adapted from Weiss et al. (1967) consists of four items. An example of item is: "An employee will leave an organization at some point in the future". 


\section{Results}

\subsection{Descriptive data}

Table 1 presents the descriptive statistics along with the alpha reliabilities for the variables used in this study. Also, correlations between the variables of the sample are reported in Table 2. Most of the scales used in the study showed good internal consistency. The alpha for the motivation to learn was 0.87 . Also, the alpha for the perceived support was 0.91 and for training attitudes 0.82 . The alpha for the affective commitment used in the current study was 0.86 . Similarly, the alpha reliability coefficients for the Job involvement, psychological contract, and turnover intention subscales were also acceptable.

\subsection{Correlations}

A preliminary examination of the correlations indicates that individual needs assessment of training and most of its antecedents are significantly correlated. For instance, the correlations between affective commitment and motivation to learn, perceived support, and training attitudes are 0.65 and 0.57 , and 0.67 (three significance at the 0.05 level), and the correlations between affective commitment and psychological contract, and job involvement are 0.51 and 0.69 (both significance at the 0.05 level). Furthermore, affective commitment is negatively related to turnover intention $(r=-.44, \mathrm{p}<.01)$. No significant differences in the measures were found among factories and thus all respondents were shared together in the subsequent analyses.

\subsection{Hypotheses Testing}

A simultaneous multiple linear regression analysis was conducted to examine hypothesis 1 of employees of a hospitality organization in Iran. The linear combination of the motivation to learn, perceived support and training attitudes explained about $25 \%$ of the variance in organizational commitment, $F(3,93)=4.35 ; \mathrm{p}<.05)$. The correlation matrix indicates a positive relationship between all three individual needs assessment and commitment (Table 2). Therefore, hypothesis 1 was supported. But, of three training needs, training attitude was found to be significant $(\mathrm{b}=0.29, \mathrm{t}=2.38, \mathrm{p}<.05)$. Therefore, training attitude emerged as a significant predictor of organizational commitment, supporting hypothesis $1 \mathrm{c}$.

A simultaneous multiple linear regression analysis is conducted to test the relationship between motivation to learn, perceived support and training attitudes and psychological contract of employees of a hospitality organization in Iran. The results indicated that $5 \%$ of the variance in psychological contract was explained by psychological contract. $F(3,91)=5.17 ; p<.05$, and the regression coefficient of psychological contract was found to be significant $(b=0.12, t=2.31 ; \mathrm{p}<.05)$. Therefore, hypothesis 4 which states that motivation to learn, perceived support, and training attitude will be positively related to psychological contract, was supported. In addition, the linear combination of motivation to learn, perceived support and training attitudes explained approximately $51 \%$ of the variance in psychological contract, $F(3,91)=12.32 ; p<.05$, and correlation matrix indicated a positive relationship between motivation to learn, perceived support and training attitudes on job involvement. Thus, hypothesis 7 was supported, which states that motivation to learn, perceived support and training attitudes will be positively related to job involvement. A simultaneous linear regression analysis was used to address and test hypothesis 3 .

Psychological contract explained approximately $18 \%$ of the variance in affective commitment $(F(1,121)=32.61$; $p<.05)$, and it was found that its regression coefficient was significant $(\mathrm{b}=.22, \mathrm{t}=4.57 ; p<.05)$. The correlation matrix indicated a positive relationship between Psychological contract and organizational commitment (Table 2). Thus, hypothesis 3 which states that psychological contract will be positively related to organizational commitment, was supported. Also, it was found that the regression coefficient of job involvement was significant $(\mathrm{b}=.32, \mathrm{t}=3.87 ; p<.05)$. The correlation matrix indicated a positive relationship between job involvement contract and organizational commitment (Table 2). Thus, hypothesis 6 which states that job involvement will be positively related to organizational commitment, was supported. A simultaneous multiple linear regression analysis was conducted to address research objective 10 and to test hypothesis 2 . Table 3 presents the results of this analysis. The results indicated that organizational commitment explained approximately $9 \%$ of the variance in intention to leave, $F(1,80)=8.32 ; p<.05$, and the regression coefficient of organizational commitment was found to be significant $(\mathrm{b}=-0.36, \mathrm{t}=-2.32 ; p<.05)$. The correlation matrix indicated a negative relationship between organizational commitment and intention to leave (Table 2). Therefore, hypothesis 2 which states that organizational commitment will have a negative relationship with intention to leave, was supported.

To test the mediating effect of psychological contract on the relationship between three training needs and organizational commitment, a summated scale of training needs was used. Motivation to learn, perceived support 
and training attitudes were combined into one single variable for training needs. The purpose of the test was to examine whether psychological contract mediated the influence of employee perceptions of the organization's training on employees' commitment level.

The mediating effect of psychological contract on the relationship between training needs and organizational commitment was examined with four stages as suggested by Baron and Kenny (1986). It was found that $19 \%$ of the variance in organizational commitment was predicted by training needs, and the regression coefficient of training needs was significant $(\mathrm{b}=.31, \mathrm{t}=4.30 ; p<.05)$. It was found that training needs became insignificant, after psychological contract was controlled $(\mathrm{b}=.11, \mathrm{t}=1.64 ; p>.05)$. The results indicated that psychological contract had a significant complete mediating effect on the relationship between training needs and organizational contract. The mediating effect of job involvement on the relationship between training needs and organizational commitment was examined with four stages as suggested by Baron and Kenny (1986). It was found that $20 \%$ of the variance in organizational commitment was predicted by training needs, and the regression coefficient of training needs was significant $(\mathrm{b}=.30, \mathrm{t}=5.30 ; p<.05)$. It was found that training needs became insignificant, after job involvement was controlled $(\mathrm{b}=.12, \mathrm{t}=1.54 ; p>.05)$. The results indicated that job involvement had a significant complete mediating effect on the relationship between training needs and organizational commitment. Therefore, hypothesis 8 which states that job involvement will mediate the relationship between training needs and organizational commitment, was supported.

\section{Conclusion}

This study aimed at investigating the relationships between affective commitment, job involvement, and psychological contract of the employees of the hospitality industry. Based on the study findings and discussions, several conclusions can be drawn from this study. First, job involvement and psychological contract are positively related to affective commitment. Committed employees contribute to the success of any hospitality company. These employees also contribute to this success by providing positive guest satisfaction. Hospitality companies must be sensitive to their employees' needs in order to provide commitment. It is in the interest of organizational managers to make every effort to increase the level of affective commitment among their employees.

In this context, suggestions for further studies could include examining job satisfaction, perceived organizational support, and other dimensions of strategic training such as task assessment and organizational assessment. Such suggestions can increase the affective commitment in tourism and hospitality in Iran. Also, a limitation of this study to be addressed is, methodology employed to test for mediation required that we make important assumptions about the direction of the relationships between the variables under study. While the data support this hypothesis, more research is needed to confirm a causal relationship.

\section{References}

Ahmad, Kamarul Zaman and Bakar, Raida Abu. (2003). The Association Between Training and Organizational Commitment Among White-Collar Workers in Malaysia. International Journal of Training and Development. 7 , 166-185.

Allen, N.J., and Meyer, J.P. (1990). The Measurement and Antecedents of Affective, Continuance and Normative Commitment to the Organization. Journal of Occupational Psychology. 63, 1-18.

Ammeter, A. P., and Dukerich, J. M. (2002). Leadership, Team Building, and Team Member Characteristics in High Performance Project Teams. Engineering Management Journal. 14(4), 3-10.

Anthony, W.P., Perrewe, P.L., and Kacmar, R.M. (1999). Human Resource Management: A Strategic Approach, The Dryden Press, Fort Worth, TX.

Argyris C. (1960). Understanding organizational behavior. Homewood, IL: Dorsey Press.

Armstrong, M. (2000). Strategic Human Resource Management: A Guide to Action. Kogan Page Publishers.

Baron, R. M., \& Kenny, D. A. (1986). The Moderator-Mediator Variable Distinction in Social Psychological Research: Conceptual, Strategic, and Statistical Considerations. Journal of Personality and Social Psychology. 51, 1173-1182.

Becker, T. S., Billings, R. S., Eveleth, D. M., and Gilbert, N. L. (1996). 'Foci and Bases of Employee Commitment: Implications For Job Performance'. Academy of Management Journal. 39, 464-82.

Becker, T. S., Billings, R. S., Eveleth, D. M., and Gilbert, N. L. (1996). 'Foci and Bases of Employee Commitment: Implications for Job Performance'. Academy of Management Journal. 39, 464-82.

Blau, G., and Boal, K., B. (1987). Conceptualizing How Job Involvement and Organizational Commitment Affect Turnover and Absenteeism. Academy of Managernent. 12(2), 288-300.

Blau, P. (1964). Exchange and power in social life. New York: Wiley.

Bunderson, J. S. (2001). How Work Ideologies Shape the Psychological Contracts of Professional Employees: 
Doctors' Responses to Perceived Breach. Journal of Organizational Behavior. 22, 717-742.

Carlson, D.S., Bozeman, D.P., and Kacmar, M. K. (2000). Training Motivation in Organizations: An Analysis of Individual-Level Antecedents. Journal of Managerial. 12 (3), 271-288.

Caykoylu, S., Egri, C. P., and Havlovic, S. (2007). Organizational Commitment Across Different Employee Groups. The Business Review. 8(1), 191-197.

Chew, J., and Chan. C. A. (2008). Human Resource Practices, Organizational Commitment and Intention to Stay. International Journal of Manpower. 29(6), 503-522.

Cook, K. S., and Rice, E. (2003). Social Exchange Theory. Handbook of Social Psychology, edited by John Delamater. Kluwer Academic/Plenum Publishers, New York.

Coyle-Shapiro, J., and Conway N. (2005). Exchange Relationships: Examining Psychological Contracts and Perceived Organizational Support. Journal of Applied Psychology. 90, 774-781

Coyle-Shapiro, J., and Kessler, I. (2000). Consequences of the Psychological Contract for the Employment Relationship: A Large Scale Survey. Journal of Management Studies.37, 903-930.

D'Annunzio-Green, N., Maxwell, G.A., and Watson, S. (2002). Human Resource Management: International Perspectives in Hospitality and Tourism. Continuum, London.

Daley, D., M. (2002). Strategic Human Resource Management: People and Performance Management in the Public Sector, Pearson Education. Prentice Hall

Deery, S. J., Iverson, R. D., and Erwin, P. J. (1994). Predicting Organizational and Union Commitment: The Effect of Industrial Relations Climate'. British Journal of Industrial Relations. 32(4), 581-97.

Dubin, S. S. (1990). Maintaining Competence Through Updating. In S. L. Willis and S. S. Dubin (Ed). Maintaining Professional Competence(pp. 9-43). San Francisco: Jossey-Bass

Eisenberger, R., Stinglhamber, F., Vandenberghe, C., Sucharski, I. L., and Rhoades, L. (2002). Perceived Supervisor Support: Contributions to Perceived Organizational Support and Employee Retention. Journal of Applied Psychology. 87(3), 565-573.

Elias, S. M. (2009). Employee Commitment in Times of Change: Assessing the Importance of Attitudes Toward Organizational Change. Journal of Management. 35 (1), 37-55.

Facteau, J. D., Dobbins, G. H., Russell, J. E. A., Ladd, R. T., and Kudisch, J. D. (1995). The influence of General Perceptions of the Training Environment on Pretraining Motivation and Perceived Training Transfer. Journal of Management. 21(1), 1-25.

Farr, J. L., and Middlebrooks, C. L. (1990). Enhancing Motivation to Participate in Professional Development. In S. L. Willis and S. S. Dubin (Ed). Maintaining Professional Competence (pp. 195-213). San Francisco: Jossey-Bass.

Farrell, D., and Rusbult, C.E. (1981). Exchange Variables as Predictors of Job Satisfaction, Job Commitment and Turnover. Organizational Behavior and Human Performance. 28 (1), 78-95.

Garger, E. M. (1999). Holding on to High Performers: A Strategic Approach to Retention.Compensation and benefits management. 15(4), 10-17.

Goldstein, I. L. (1991). Training in Work Organizations. In M. D. Dunnette and L. M. Hough (Ed). Handbook of Industrial and Organizational Psychology(pp. 507-619). Palo Alto, CA: Consulting Psychologists Press.

Goldstein, I. L. (1992). Training in Organizations. ( ${ }^{\text {rd }}$ ed.) Pacific Grove, CA: Brooks/Cole.

Goldstein, Irwin, L. (1993). Training in Organization: Needs Assessment, Development and Evaluation (3rd Ed.). California: Brooks/Cole Publishing Company.

Gomez-Mejia, L.R., Balkin, D.B., and Cardy, R.L. (1995). Managing Human Resources. Englewood Cliffs, N. J.: Prentice-Hall.

Griffeth, R. W., \& Hom, P. W. (1995). The employee turnover process. Research in Personnel and Human Resources Management, 13, 245-293.

Gu"c, lu", H. (2006). Turizm sekto"ru“nde durumsal fakto" rlerin o"rgu" tsel bag lllık u"zerine etkisi ("The effects of situational factors on organizational commitment in tourism sector"), Anadolu U" niversitesi Yayını No. 1691, Anadolu U“" niversitesi, Eskis, ehir.

Guest, D. (1987). Human Resource Management and Industrial Relations. Journal of Management Studies. 24, 503-521.

Guzzo, R. A., Noonan, K. A., and Elron E. (1994). Expatriate Managers and the Psychological Contract. Journal of Applied Psychology. 79, 617-626.

Hammer, L. B., Kossek, E.F., Yragui, N. L., Bonder, T. E., and Hanson, G. C. (2009). Development and Validation of a Multidimensional Measure of FamilySupportive Supervisor Behaviors (FSSB). Journal of Management. 35(4), 837-856.

Hicks, W. D. (1984). The Process of Entering Training Programs and Its Effects on Training Outcomes. 
Dissertation Abstracts. 44, 35648 (University Microfilms No. DA8403528).

Huczynski, A. A., and Lewis, J. W. (1980). An Empirical Study into the Learning Transfer Process in Management Training. The Journal of Management Studies. 17, 227-40.

Huselid, M. A., Jackson, S.E., and Schuler, R.S. (1997). Technical and Strategic Human Resource Management Effectiveness as Determinants of Firm Performance. Academy of Management Journal. 40(1), 171-188. [Online] Available: http: //humanresources. about.com /od/trainingneedsassessment / Training_Needs_Assessment. htm Igharia, M., \& Greenhaus, J. H. (1992). Determinants of MIS employees' turnover intentions: A structural equation model. Association for Computing Machinery. Communications of the ACM, 35(2), 34-49.

Iles, P., Mabey, C., and Robertson, I. (1990). HRM Practices and Employee Commitment: Possibilities, Pitfalls and Paradoxes'. British Journal of Management. 1(3), 147-157.

Iverson, R. D., and Buttigieg, D.M (1999). Affective, Normative and Continuance Commitment: Can the 'Right Kind' of Commitment Be Manage. Journal of Management Studies. 36(3).

King, J. (2000). White Collar Reactions to Job Insecurity and the Role of the Psychological Contract: Implications for Human Resource Management. Human Resource Management. 39(1), 79-92.

Lang, D.L. (1992). Organizational Culture and Commitment. Human Resource Development Quarterly. 3(2), 191-196.

Lester, S. W., Turnley, W. H., Bloodgood, J. M., and Bolino, M. C. (2002). Not Seeing Eye to Eye: Differences in Supervisor and Subordinate Perceptions of and Attributions for Psychological Contract Breach. Journal of Organizational Behavior. 23, 39-56.

Levinson H, Price C, Munden K, Mandl H, and Solley C. (1962). Men, management, and mental health. Cambridge, MA: Harvard University Press. Schein EH. (1965). Organizational psychology. Englewood Cliff, NJ: Prentice Hall.

Lodahl, T., and Kejner, M. (1965). The Definition and Measurement of Job Involvement. Journal of applied Psychology, 49, 23-33.

Loi, R., Hang-yue, N., \& Foley, S. (2006). Linking Employees' Justice Perceptions to Organizational Commitment and Intention to Leave: The Mediating Role Of Perceived Organizational Support. Journal of Occupational and Organizational Psychology. 79, 101-120.

Mahmoodi, S. (2007). بنامه ريزى استراتزيك[The Strategic Planning]. بديريك), 2(3), 56-68.

Mathieu, J. E., and Martineau, J. W. (1997). Individual and Situational Influences in Training Motivation. in: J.K. Ford et al., Editors, Improving training effectiveness in work organizations.( pp. 193-222). Mahwah, N. J.: Lawrence Erlbaum Associates.

Mathieu, J.E., and Zajac, D.M. (1990). A Review and Meta-Analysis of the Antecedents, Correlates, and Consequences of Organizational Commitment. Psychological Bulletin. 108(2), 171-194

McInnis, K. J., Meyer, J. P., and Feldman, S. (2009). Psychological Contracts and Their Implications for Commitment: A Feature-Based Approach. Journal of Vocational Behavior. 74, 165-180.

Mello, J. A. (2002). Strategic Human Resource Management. Ohio: South-Western.

Meyer, J. P., \& Allen, N. J. (1991). A Conceptualization of Organizational Commitment. Human Resource Management Review, 1, 61-89.

Meyer, J. P., Allen, N. J., and Smith, C. A. (1993). 'Commitment to Organizations and Occupations: Extension and Test of A Three-Component Conceptualization'. Journal of Applied Psychology. 78, 4, 538-551.

Meyer, J. P., Allen, N. J., and Gellatly, I. R. (1990). 'Affective and Continuance Commitment to the Organization: Evaluation of Measures and Analysis of Concurrent and Time-Lagged Relations'. Journal of Applied Psychology. 75, 710-720.

Meyer, J. P., and Allen, N. J. (1984). Testing the "Side-Bet Theory" of Organizational Commitment: Some methodological considerations. Journal of Applied Psychology. 69,372-378.

Meyer, J. P., and Allen, N. J. (1991). A Three Component Conceptualization of Organizational Commitment. Human Resource Management. 1, 61-89.

Meyer, J. P., and Allen, N. J. (1997). Commitment in the Workplace: Theory, Research, and Application. Thousand Oaks, CA: Sage.

Meyer, J. P., Paunonen, S. V., Gellatly, I. R., Goffin, R. D., and Jackson, D. N. (1989). 'Organizational Commitment and Job Performance: It's The Nature of The Commitment That Counts'. Journal of Applied Psychology. 74, 152-156.

Meyer, J.P., Stanley, D.J., Herscovitch, L., \& Topolnytsky, L. (2002). Affective, Continuance, and Normative Commitment to the Organization: A Meta-Analysis of Antecedents, Correlates, and Consequences. Journal of Vocational Behavior.61, 20-52.

Noe, R. A., and Schmitt, N. (1986). The Influence of Trainee Attitudes on Training Effectiveness. Test of A Model. 
Personnel psychology. 39, 497-523.

Porter, L.W., Steers,R.M., and Boulian,P (1974). Organizational Commitment, Job Satisfaction and Turnover Among Psychiatric Technicians. Journal of Applied Psychology. 59, 603-609.

Richard, P. J., Devinney, T. M., Yip, G. S., and Johnson, G. (2009). Measuring Organizational Performance: Towards Methodological Best Practice. Journal of Management. 35(3), 718-804.

Robinson SL. (1996). Trust and Breach of the Psychological Contract. Administrative Science Quarterly. 41, 574-599.

Roehling, M. V. (1997). The Origins and Early Development of the Psychological Contract Construct. Journal of Management History. 3(2), 204-217.

Rousseau DM and Tijoriwala SA. (1998). Assessing Psychological Contracts: Issues, Alternatives and Measures. Journal of Organizational Behavior. 19, 679-695.

Rousseau DM. (1989). Psychological and implied contracts in organizations. Employee Responsibilities and Rights Journal. 2, 121-139.

Rousseau DM. (1995). Psychological Contracts in Organizations: Understanding Written and Unwritten Agreements. Thousand Oaks, CA: Sage.

Rousseau, D. M., \& Greller, M. M. (1994). Human Resource Practices: Administrative Contract Makers. Human Resource Management. 33(3), 385-401.

Rousseau, D. M., \& Wade-Benzoni, K. A. (1994). Linking Strategy And Human Resource Practices: How Employee and Customer Contracts are Created. Human Resource Management. 33(3), 463-489.

Rousseau, D.M. (1990). New Hire Perceptions of Their Own and Their Employer's Obligations: A Study of Psychological Contracts. Journal of Organizational Behavior. 11, 389- 400.

Saks, A. M. (1995). Longitudinal Field Investigation of the Moderating And Mediating Effects of Self-Efficacy on the Relationship Between Training and Newcomer Adjustment. Journal Of Applied Psychology. 80(2), 211-225.

Salaman, G., J. Storey and J. Billsberry. (2005). Strategic Human Resource Management: A Reader, $2^{\text {nd }}$ edition. London: Sage.

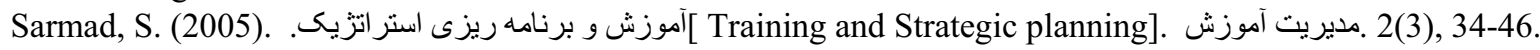

Schalk, R., and Roe, R. E. (2007). Towards a Dynamic Model of the Psychological Contract. Journal of the Theory of Social Behavior. 37, 167-182.

Schein, E. H. (1965). Organizational psychology. New Jersey: Englewood Cliffs.

Sels, L., Janssens, M., and Van den Brande, I. (2004). Assessing the Nature of Psychological Contracts: A Validation of Six Dimensions. Journal of Organizational Behavior. 25 (4), 461-488.

Shore, L., M., Tetrick, L. E., Taylor, S., Shapiro, J.A-MC, Liden, R. C and Parks, J. M, et al L. (2004). The employee organization relationship: A timely concept in a period of transition. In Martocchio JJ (Ed.), Research in personnel and human resource management, 23, (pp. 291-370). Elsevier.

Storey, J. and Sisson, K. (1993). Managing Human Resources and Industrial Relations. Buckingham: Open University Press.

Tannenbaum, S. I., Mathieu, J. E., Salas, E., \& Cannon-Bowers, J. A. (1991). Meeting Trainees' Expectations: The Influence of Training Fulfilment on the Development of Commitment, Self Efficacy, and Motivation. Journal of Applied Psychology.76, 759-769.

Taylor SM., and Tekleab AG. (2004). Taking stock of psychological contract research: Assessing progress, addressing troublesome issues, and setting research priorities. In Coyle- Shapiro JA-M, Shore LM, Taylor SM, Tetrick LE (Eds.), The employment relationship: Examining psychological and contextual perspectives. New York: Oxford University Press.

Thomas, K. W. (2000). Intrinsic Motivation at Work: Building energy and commitment. San Francisco: Berrett Koehler Publisher, Inc.

Thompson, C. A., and Prottas, D. (2005). Relationships Among Organizational Family Support, Job Autonomy, Perceived Control, And Employee Well-Being. Journal of Occupational Health Psychology. 11(1), 100-118.

Thompson, C. A., Beauvais, L. L., \& Lyness, K. S. (1999). When Work-Family Benefits Are Not Enough: the Influence of Work-Family Culture on Benefit Utilization, Organizational Attachment, and Work-Family Conflict. Journal of Vocational Behavior. 54, 392-415.

Weinstein, C. E., Palmer, D. R., Hanson, G. R., Dierking, D. R., McCann, E., Soper, M., and Nath, I. (1994). Design and Development of An Assessment of Readiness for Training: the START. Annual Conference of the Academy of Human Resource Development. March, San Antonio, TX.

Weiss, D. J., Dawis, R. V., England, G. W., \& Lofquist, L. H. (1967). Manual for the Minnesota Satisfaction Questionnaire. Minneapolis, MN: University of Minnesota. 
Williams, L., J., and Hazer, J., T. (1986). Antecedents and Consequences of Satisfaction and Commitment in Turnover Models: A Reanalysis Using Latent Variables Structural Equation Methods. Journal of Applied Psychology. 71 (2), 219-31.

Zhao, H, Wayne, S. J., Glibkowski, B.C., and Jesus Bravo, J. (2007). The Impact of Psychological Contract Breach on Work-Related Outcomes: A Meta-Analysis. Personnel Psychology. 60, 647-680.

Table 1. Descriptive of All Variables

\begin{tabular}{llllc} 
Variable & N of items & M & SD & Alpha \\
Motivation to learn & 12 & 46.2 & 4.12 & 0.87 \\
\hline Perceived support & 16 & 54.1 & 13.98 & 0.91 \\
Training Attitude & 7 & 3.88 & 5.78 & 0.82 \\
Affective commitment & 6 & 18.47 & 4.21 & 0.86 \\
\hline Job involvement & 6 & 18.34 & 4.23 & 0.52 \\
Psychological contract & 12 & 53.24 & 13.92 & 0.90 \\
Intention to leave & 4 & 8.35 & 3.62 & 0.70 \\
\hline \multicolumn{2}{c}{ M= mean ; SD = standard deviation. DV = dependent variable; IV = independent variable. } \\
\hline
\end{tabular}

Table 2. Correlation Matrix

\begin{tabular}{lllllllll}
\hline & 1 & 2 & 3 & 4 & 5 & 6 & 7 \\
\hline 1. & Motivation to learn & 1.00 & & & & & & \\
2. & Perceived support & 0.69 & 1.00 & & & & & \\
3. & Training attitude & 0.54 & 0.66 & 1.00 & & & & \\
4. & Affective commitment & 0.65 & 0.57 & 0.67 & 1.00 & & & \\
5. & Job involvement & 0.60 & 0.81 & 0.65 & 0.69 & 1.00 & & \\
6. & Psychological contract & 0.67 & 0.61 & 0.75 & 0.51 & 0.59 & 1.00 & \\
7. & Turnover intention & -0.42 & -0.35 & -0.32 & -0.44 & -0.39 & -0.34 & 1.00
\end{tabular}

All variables were measured on a 5 -point scale, $1=$ strongly disagree, $7=$ strongly agree.

$* p<.05$

Table 3. Results of Regression Analysis of organizational commitment on turnover intention

$\begin{array}{lccc}\text { Variable } & \mathrm{b} & \mathrm{t} & \mathrm{p} \text { - value } \\ \text { Constant } & 5.33 & 7.88 & 0.01 \\ \text { organizational commitment } & -0.36 & -2.32 & 0.01 \\ \mathrm{R}^{2} 0.26 & & & \\ \text { Adjusted } \quad \mathrm{R}^{2}=.09 & & & \\ \mathrm{~F}=8.32 * & & & \\ * p \leq .05 & & & \end{array}$


Table 4. Results of regression analysis of the mediating effect of psychological contract on the relationship between individual needs assessment of training and affective commitment

\begin{tabular}{|c|c|c|c|c|c|c|c|c|}
\hline \multirow{3}{*}{ Variable } & \multicolumn{2}{|c|}{ Stage 1} & \multicolumn{2}{|c|}{ Stage 2} & \multicolumn{2}{|c|}{ Stage 3} & \multicolumn{2}{|c|}{ Stage 4} \\
\hline & \multicolumn{2}{|l|}{$\mathrm{AC}$} & \multicolumn{2}{|c|}{$\mathrm{PC}$} & \multicolumn{2}{|c|}{$\mathrm{AC}$} & \multicolumn{2}{|c|}{$\mathrm{AC}$} \\
\hline & $\mathrm{b}$ & $\mathrm{t}$ & $\mathrm{b}$ & $\mathrm{t}$ & $\mathrm{b}$ & $\mathrm{t}$ & $\mathrm{b}$ & $\mathrm{t}$ \\
\hline Constant & 2.67 & 9.23 & 1.71 & 3.62 & 4.18 & 48.96 & 2.80 & 9.20 \\
\hline $\begin{array}{l}\text { Training } \\
\text { needs }\end{array}$ & 0.31 & 4.30 & 0.29 & 2.54 & & & 2.54 & 4.68 \\
\hline PC & & & & & 0.15 & 2.27 & 0.06 & 1.64 \\
\hline
\end{tabular}

Table 5. Results of regression analysis of the mediating effect of job involvement on the relationship between individual needs assessment of training and affective commitment

\begin{tabular}{|c|c|c|c|c|c|c|c|c|}
\hline \multirow{3}{*}{ Variable } & \multirow{2}{*}{\multicolumn{2}{|c|}{$\begin{array}{l}\text { Stage } 1 \\
\mathrm{AC}\end{array}$}} & \multirow{2}{*}{\multicolumn{2}{|c|}{$\begin{array}{c}\text { Stage } 2 \\
\text { JI }\end{array}$}} & \multirow{2}{*}{\multicolumn{2}{|c|}{$\begin{array}{c}\text { Stage } 3 \\
\mathrm{AC} \\
\end{array}$}} & \multirow{2}{*}{\multicolumn{2}{|c|}{$\begin{array}{c}\text { Stage } 4 \\
\mathrm{AC}\end{array}$}} \\
\hline & & & & & & & & \\
\hline & $\mathrm{b}$ & $\mathrm{t}$ & $\mathrm{b}$ & $\mathrm{t}$ & $\mathrm{b}$ & $\mathrm{t}$ & $\mathrm{b}$ & $\mathrm{t}$ \\
\hline Constant & 2.67 & 9.23 & 1.39 & 3.52 & 2.80 & 11.71 & 2.31 & 8.04 \\
\hline Training needs & 0.30 & 5.30 & 0.77 & 9.05 & & & 0.12 & 1.54 \\
\hline JI & & & & & 0.28 & 5.97 & 0.25 & 3.67 \\
\hline
\end{tabular}

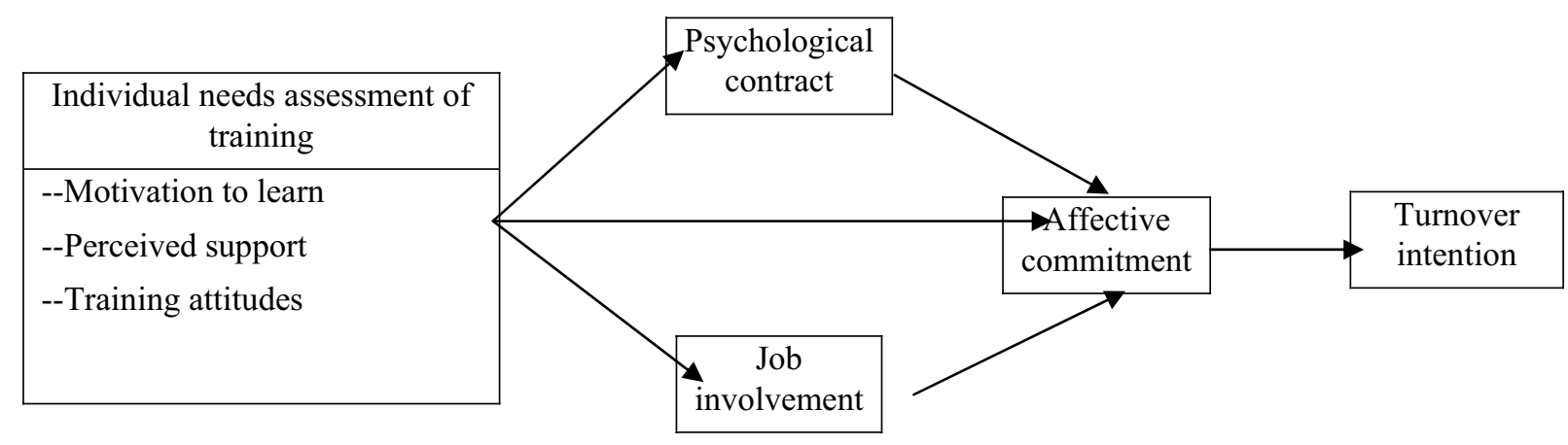

Figure 1. Conceptual Model 